OPEN ACCESS

Edited by:

Maurizio Muscaritoli,

Sapienza University of Rome, Italy

Reviewed by:

Dario Coletti,

Sapienza University of Rome, Italy

Irena Keser

University of Zagreb, Croatia

*Correspondence:

Gabriella Peron

gabriella.peroni01@universitadipavia.it

Specialty section:

This article was submitted to

Clinical Nutrition,

a section of the journal

Frontiers in Nutrition

Received: 28 October 2020 Accepted: 30 December 2020

Published: 26 January 2021

Citation:

Rondanelli M, Nichetti M, Peroni G,

Faliva MA, Naso M, Gasparri C, Perna S, Oberto L, Di Paolo E, Riva A,

Petrangolini G, Guerreschi $G$ and

Tartara A (2021) Where to Find

Leucine in Food and How to Feed

Elderly With Sarcopenia in Order to

Counteract Loss of Muscle Mass:

Practical Advice.

Front. Nutr. 7:622391

doi: 10.3389/fnut.2020.62239

\section{Where to Find Leucine in Food and How to Feed Elderly With Sarcopenia in Order to Counteract Loss of Muscle Mass: Practical Advice}

\author{
Mariangela Rondanelli ${ }^{1,2}$, Mara Nichetti ${ }^{3}$, Gabriella Peroni ${ }^{3 *}$, Milena Anna Faliva ${ }^{3}$, \\ Maurizio Naso ${ }^{3}$, Clara Gasparri ${ }^{3}$, Simone Perna ${ }^{4}$, Letizia Oberto ${ }^{3}$, Enrica Di Paolo ${ }^{5}$, \\ Antonella Riva ${ }^{6}$, Giovanna Petrangolini ${ }^{6}$, Giulia Guerreschi ${ }^{3}$ and Alice Tartara ${ }^{3}$ \\ ${ }^{1}$ Istituto di Ricovero e Cura a Carattere Scientifico (IRCCS) Mondino Foundation, Pavia, Italy, ${ }^{2}$ Department of Public Health, \\ Experimental and Forensic Medicine, University of Pavia, Pavia, Italy, ${ }^{3}$ Endocrinology and Nutrition Unit, Azienda di Servizi \\ alla Persona "Istituto Santa Margherita", University of Pavia, Pavia, Italy, ${ }^{4}$ Department of Biology, College of Science, \\ University of Bahrain, Zallaq, Bahrain, ${ }^{5}$ General Geriatric Unit, Azienda di Servizi alla Persona "Istituto Santa Margherita", \\ Pavia, Italy, ${ }^{6}$ Research and Development Department, Indena SpA, Milan, Italy
}

The term sarcopenia refers to the loss of skeletal muscle mass and strength that generally occurs during aging. The interventions that have proved most effective in reducing the severity and preventing the worsening of sarcopenia include physical exercise, especially resistance, and the administration of dietary supplements in association with a targeted diet; nutritional intervention is the main therapeutic approach for elderly people, since they are very often sedentary (also due to possible disabilities). Among the various nutrients, high biological value proteins and leucine are of particular interest for their demonstrated effects on the health of skeletal muscle. The intake of food containing proteins and leucine during meals stimulates muscle protein synthesis. Lower blood levels of leucine were associated with lower values of the skeletal muscle index, grip strength and performance. The international guidelines recommended that a leucine intake of $3 \mathrm{~g}$ at three main meals together with 25-30 g of protein is the goal to be achieved to counteract loss of lean mass in elderly. Food composition databases rarely show the amounts of leucine contained in foods and therefore it becomes difficult to build a diet that follows these guidelines. A table was therefore created for the first time in the literature to collect all the foods richest in leucine, thanks to the union of the most important Italian food databases. Moreover, in order to implement a diet that follows the right recommendations, another tables shows nutritional composition of breakfast, lunch and dinner (that each provide 3 grams of leucine and 25 grams of protein) for seven days.

Keywords: leucine, proteins, sarcopenia, elderly, diet

\section{INTRODUCTION}

The term sarcopenia refers to the loss of skeletal muscle mass and strength that generally occurs during aging (from the age of 50); in individuals aged $60-70$, a prevalence of about $5-13 \%$ has been estimated, which increases to $11-50 \%$ after the age of 80 , with a consequent increase in physical disability, poor quality of life and increased morbidity and mortality in this slice of the population $(1,2)$. 
The interventions that have proved most effective in reducing the severity and preventing the worsening of sarcopenia include physical exercise, especially resistance, and the administration of dietary supplements in association with a targeted diet; nutritional intervention remains the main therapeutic approach in elderly people, since they are very often sedentary (also due to possible disabilities) (3). Among the various nutrients, high biological value proteins and leucine are of particular interest for their demonstrated effects on the health of skeletal muscle (4). The intake of food containing protein during meals stimulates muscle protein synthesis, with a peak about $2-3 \mathrm{~h}$ after ingestion (5). Aging is associated with muscle resistance to the anabolic effects of diet, with a reduced response to postprandial hyperaminoacidemia, in terms of muscle protein synthesis, compared to young adults $(6,7)$. The international guidelines recommended that a leucine intake of $3 \mathrm{~g}$ at three main meals together with 25-30 g of protein is the goal to be achieved to counteract loss of lean mass in elderly (8).

Food composition databases rarely show the amounts of leucine contained in foods and therefore it becomes difficult to build a diet that follows these guidelines.

Given this background, the aim of this narrative review is to evaluate the literature and the food composition databases which considered the leucine content on food, by building tables with leucine content in food, in order to prepare practical advice for sarcopenic elderly.

\section{MATERIALS AND METHODS}

The present narrative review was performed following the steps by Egger et al. (9) as follows:

1. Configuration of a working group: three operators skilled in clinical nutrition (one acting as a methodological operator and two participating as clinical operators).

2. Formulation of the revision question on the basis of considerations made in the abstract: "because food composition databases rarely show the amounts of leucine contained in foods, the aim of this narrative review is to evaluate the literature and the food composition databases which considered the leucine content on food, by building tables with leucine content in food, in order to prepare practical advice for sarcopenic elderly".

3. Identification of relevant studies: a research strategy was planned on PubMed (Public MedIine run by the National Center of Biotechnology Information (NCBI) of the National Library of Medicine of Bathesda (USA)) as follows: (a) Definition of the keywords (leucine, food, muscle mass), allowing the definition of the interest field of the documents to be searched, grouped in quotation marks (“...”) and used separately or in combination; (b) use of: the Boolean (a data type with only two possible values: true or false) AND operator, that allows the establishments of logical relations among concepts; (c) Research modalities: advanced search; (d) Limits: time limits: papers published in the last 20 years; humans; adults; languages: English; (e) Manual search performed by the senior researchers experienced in clinical nutrition through the revision of reviews, individual articles and food composition databases.

4. The analysis was carried out in the form of a narrative review of the reports.

\section{RESULTS}

\section{The Pivotal Role of Leucine in Order to Counteract the Loss of Muscle Mass}

Metabolic studies have shown that subjects $\geq 65$ years of age require about $2 \%$ more protein per meal in order to maximize muscle protein synthesis, and leucine supplementation has been shown to be potentially useful for this purpose $(3,10)$. L-leucine is an essential non-polar aliphatic, branched-chain amino acid (branched-chain amino acid, BCAA, such as L-valine and Lisoleucine), with regulatory functions on the muscle mediated, at least in part, by the action of mTOR (mammalian Target Of Rapamycin, target of rapamycin in mammals, a serine-threonine protein kinase) $(3,11)$. MTOR, and the signal transduction pathways that originate from it, regulate protein synthesis and act as energy "sensors" of nutrients and the availability of amino acids (leucine in particular); mTOR is activated when ATP levels are high, and blocked when ATP levels are low (12). In general, BCAAs, unlike other amino acids, which are oxidized mainly in the liver, are metabolized mainly in skeletal muscle, where the most active oxidation system of branched chain amino acids is located, including the BCAT (branched-chain aminotransferase) enzyme (13). Leucine, in particular, acts directly, as a signal molecule, through the activation of the mTORC1 complex, which regulates the homeostasis of proteins by stimulating the processes of translation and muscle protein synthesis in response to amino acids (phosphorylation of the translation initiation factor $4 \mathrm{E}$ $\mathrm{BP} 1)$ and repressing protein degradation $(6,14)$; furthermore, its integration has appeared to improve mitochondrial function in skeletal muscles $(3,11)$. At the muscle level, therefore, leucine decreases proteolysis and stimulates protein synthesis, while at the level of pancreatic beta-cells it has a secretagogue effect, enhancing the glucose-induced release of insulin. Furthermore, this amino acid can stimulate the synthesis and secretion, by the L cells of the ileum and colon, of GLP-1 (Glucagon-Like Peptide 1 ), which increases the insulin response of muscle cells, thus improving the 'glucose intake and, consequently, anabolism and the maintenance of muscle mass itself $(3,11)$.

\section{Leucine Blood Levels and Muscle Mass and Performance}

As for the plasma levels of branched chain amino acids, and therefore also of leucine, they seem to be influenced by changes in the dietary intake of nutrients. From observations on humans and animal models, for example, an increase in the concentrations of these amino acids emerged following a period of fasting, while protein deprivation was associated with a decrease. In the first case, the main responsible mechanism would be an increase in muscle protein degradation, aimed at providing substrates for hepatic gluconeogenesis and the oxidation of BCAAs in the muscles; in the second case, the absence of 
exogenous amino acids and the reduced muscle protein turnover would explain the decrease in plasma levels of BCAA (15). In the post-prandial period, on the other hand, a rapid increase was observed in 11 healthy male volunteers aged between 40 and 61 years, followed by the uptake of BCAA by muscle tissue, and these plasma concentrations were still elevated $12 \mathrm{~h}$ after a high protein meal (4,850 kJ of energy, of which $40 \%$ provided by protein, $30 \%$ by fat and another $30 \%$ by carbohydrates) compared to a low protein meal $(3,770 \mathrm{~kJ}$ of energy: $15 \%$ deriving from proteins, $25 \%$ from fats and $60 \%$ from carbohydrates) (16). A Canadian study of 2019 on 199 subjects aged 18-55, however, found no association between fasting plasma levels of BCAAs (sample mean: $455.6 \pm 92.3 \mu \mathrm{M}$ ) and their dietary intake (value average: $18.5 \pm 6.8 \mathrm{~g} /$ day); a weak correlation was instead found between plasma concentration of branched chain amino acids and intake of proteins of animal origin and red meat (17).

In a sample of 232 elderly Japanese women (mean age 79.4 \pm 7.0 years) significantly lower blood leucine concentrations were found in subjects with dinapenia (defined by the authors as decreased muscle function without loss of muscle mass) and sarcopenia compared to normal subjects. More generally, in women with dinapenia and sarcopenia the concentrations of BCAAs were lower than in normal women and women with pre-sarcopenia (reduced muscle mass without decreased muscle function) (18). Similarly, in a Norwegian cross-sectional study, conducted on 417 elderly subjects (age $\geq 70$ years), after adjustment of the data for gender, it was found that the plasma concentrations of leucine and isoleucine, after a mean of $2 \mathrm{~h}$ and $18-24 \mathrm{~min}$ from the last meal, are significantly lower in participants diagnosed with sarcopenia than in healthy ones, as well as absolute dietary protein intake and energy intake assessed by two 24-h recall. Adjusting, however, the data also for body weight, no difference in protein intake was highlighted between the two groups. Furthermore, plasma leucine levels correlated positively with skeletal muscle mass and grip strength. However, it remains to be clarified whether the low dietary intake of proteins over time is the cause of the low plasma concentrations of BCAAs, and whether the levels of leucine in particular can be used as biomarker of sarcopenia; in fact, to date, no optimal or minimum plasma values necessary for the maintenance of skeletal muscle mass have been defined for branched chain amino acids (19). Furthermore, using data from the Maastricht Sarcopenia study (MaSS) cross-sectional study of 227 community-resident seniors (mean age 74 years), Ter Borg S. and colleagues observed lower blood levels of essential amino acids, branched chain amino acids and leucine were associated with lower values of the skeletal muscle index (SMI) and grip strength and a longer time required to complete the chair stand test; moreover, the condition of sarcopenia was more frequent among subjects with lower levels of leucine, BCAAs and essential amino acids (EAAs) (20). Moreover, some comparative studies have investigated the differences in the plasma amino acid profile of healthy individuals belonging to different age groups. Comparing between them 27 young subjects (10 males of $26.3 \pm 0.8$ years and 17 females of $25.0 \pm 0.6$ years), 40 elderly (20 males of $75.8 \pm 0.5$ years and 20 females of $76.3 \pm$ 0.8 years) and 32 centenarians (nine males of $101.9 \pm 1.0$ years
TABLE 1 | Content in leucine, protein and energy per $100 \mathrm{~g}$ of food (in descending order of leucine).

\begin{tabular}{|c|c|c|c|}
\hline Food & $\begin{array}{l}\text { Leucine } \\
(\mathrm{g} / 100 \mathrm{~g})\end{array}$ & $\begin{array}{l}\text { Total protein } \\
(\mathrm{g} / 100 \mathrm{~g})\end{array}$ & $\begin{array}{c}\text { Energy } \\
\text { (kcal/100 g) }\end{array}$ \\
\hline \multicolumn{4}{|l|}{ Meat } \\
\hline Adult bovine's rump & 1,894 & 22 & 111 \\
\hline Baked ham & 1,695 & 19.8 & 215 \\
\hline $\begin{array}{l}\text { Bovine, calf, } 4 \text { months, low-fat } \\
\text { meat }\end{array}$ & 1,029 & 20.7 & 92 \\
\hline $\begin{array}{l}\text { Bovine, calf, } 4 \text { months, } \\
\text { semi-fat meat }\end{array}$ & 1,742 & 20.3 & 144 \\
\hline Bresaola & 2,651 & 32 & 152 \\
\hline Chicken's breast, without skin & 1,955 & 23.3 & 100 \\
\hline Chicken's wings, without skin & 1,717 & 20.3 & 193 \\
\hline Deer, without visible fat & 1,953 & 21 & 91 \\
\hline $\begin{array}{l}\text { Guinea fowl's breast, without } \\
\text { skin }\end{array}$ & 2,180 & 25,8 & 121 \\
\hline $\begin{array}{l}\text { Guinea fowl's thigh, without } \\
\text { skin }\end{array}$ & 1,829 & 24 & 127 \\
\hline Horse, fat and muscle tissue & 1,519 & 19,8 & 145 \\
\hline Lamb & 1,532 & 20 & 159 \\
\hline Melted chicken, without skin & 1,526 & 18.5 & 107 \\
\hline $\begin{array}{l}\text { Pork low-fat steak, without } \\
\text { visible fat }\end{array}$ & 1,741 & 21.3 & 157 \\
\hline Pork's sausage & 1,241 & 15,4 & 304 \\
\hline Pork's shoulder & 1,550 & 19 & 156 \\
\hline Rabbit, low-fat meat & 1,987 & 23.7 & 102 \\
\hline Raw ham & 2,211 & 26.6 & 284 \\
\hline Speck & 2,326 & 28,3 & 303 \\
\hline Turkey's breast, without skin & 2,002 & 24 & 107 \\
\hline Turkey's thigh, without skin & 1,438 & 18 & 113 \\
\hline \multicolumn{4}{|l|}{ Cheese, milk and yogurt } \\
\hline Asiago & 2,845 & 31.4 & 359 \\
\hline Cow ricotta & 0,997 & 8.8 & 146 \\
\hline Cow's milk partially skimmed & 0,377 & 3.5 & 46 \\
\hline Crescenza & 1,250 & 16.1 & 281 \\
\hline Emmenthal & 2,687 & 28.5 & 403 \\
\hline Feta & 1,531 & 15,6 & 250 \\
\hline Gorgonzola & 1,530 & 19,1 & 324 \\
\hline Grana cheese & 2,820 & 33.9 & 406 \\
\hline Greek yogurt & 0,505 & 6.4 & 115 \\
\hline Greek yogurt, low-fat & 0,707 & 9 & 51 \\
\hline Gruyer & 3,184 & 30.6 & 389 \\
\hline Italico & 2,071 & 21.2 & 316 \\
\hline Milk flakes & 0,978 & 9.7 & 115 \\
\hline Mozzarella cheese & 1,400 & 18.7 & 253 \\
\hline Parmesan & 2,880 & 33.5 & 387 \\
\hline Robiol & 1,467 & 20 & 338 \\
\hline Spreadable cheese & 0,933 & 8.6 & 313 \\
\hline Yogurt partially skimmed & 0,268 & 3.4 & 43 \\
\hline \multicolumn{4}{|l|}{ Fish } \\
\hline Anchovy & 1,331 & 16,8 & 96 \\
\hline Clam & 0,718 & 10.2 & 72 \\
\hline Cod & 1,484 & 17 & 71 \\
\hline Cod steaks & 0,862 & 11 & 191 \\
\hline
\end{tabular}


TABLE 1 | Continued

\begin{tabular}{|c|c|c|c|}
\hline Food & $\begin{array}{l}\text { Leucine } \\
\text { (g/100 g) }\end{array}$ & $\begin{array}{l}\text { Total protein } \\
(\mathrm{g} / 100 \mathrm{~g})\end{array}$ & $\begin{array}{c}\text { Energy } \\
\text { (kcal/100 g) }\end{array}$ \\
\hline Cuttlefish & 0,985 & 14 & 72 \\
\hline Dog fish & 1,300 & 16 & 80 \\
\hline Drained tuna in oil & 2,029 & 25.2 & 192 \\
\hline Farmed sea bream, filets & 1,557 & 19.7 & 159 \\
\hline Frozen shrimps & 1,179 & 13.6 & 63 \\
\hline Grouper & 1,455 & 17.9 & 80 \\
\hline Herring & 1,341 & 16.5 & 216 \\
\hline Mackerel & 1,636 & 17 & 170 \\
\hline Mullet roe & 2,822 & 35,5 & 373 \\
\hline Mussel & 0,824 & 11,7 & 84 \\
\hline Octopus & 0,746 & 10,6 & 57 \\
\hline Persic fish & 1,252 & 15.4 & 75 \\
\hline Salmon & 1,496 & 18.4 & 185 \\
\hline Sardines & 1,643 & 20,8 & 129 \\
\hline Smoked salmon & 2,065 & 25.4 & 147 \\
\hline Soaked cod & 1,886 & 21.6 & 95 \\
\hline Sole & 1,336 & 16.9 & 86 \\
\hline Squid & 0,886 & 12,6 & 68 \\
\hline Surimi & 1,204 & 15.2 & 95 \\
\hline Sword fish & 1,373 & 16.9 & 109 \\
\hline Trout & 1,028 & 14.7 & 86 \\
\hline Tuna fish & 1,871 & 21.5 & 159 \\
\hline \multicolumn{4}{|l|}{ Legumes } \\
\hline Beans & 0,488 & 6,4 & 104 \\
\hline Borlotti beans dried, boiled & 0,563 & 6,9 & 106 \\
\hline Borlotti beans, boiled & 0,493 & 5,7 & 78 \\
\hline $\begin{array}{l}\text { Cannellin beans dried, cooked, } \\
\text { boiled }\end{array}$ & 0,682 & 8 & 107 \\
\hline $\begin{array}{l}\text { Cannellin beans, canned, } \\
\text { drained }\end{array}$ & 0,513 & 6 & 86 \\
\hline Chick peas dried, boiled & 0,549 & 7 & 132 \\
\hline Lentils, drained canned & 0,417 & 5 & 91 \\
\hline Lentils, dried boiled & 0,527 & 6,9 & 109 \\
\hline Peas, dried & 1,406 & 21,7 & 306 \\
\hline Raw dried broad beans & 2,119 & 27,2 & 343 \\
\hline \multicolumn{4}{|l|}{ Cereals } \\
\hline Bread & 0,691 & 9 & 275 \\
\hline Buckwheat & 0,837 & 12,4 & 329 \\
\hline Corn & 1,168 & 9,2 & 357 \\
\hline Corn flour & 1,028 & 8.7 & 341 \\
\hline Millet & 1,389 & 11,8 & 343 \\
\hline Oat flour & 0,920 & 12,6 & 378 \\
\hline Polished rice & 0,590 & 6,7 & 334 \\
\hline Rusks & 0,831 & 11,3 & 387 \\
\hline Semolina pasta & 1,033 & 13,5 & 341 \\
\hline Spelled perlat, raw & 1,075 & 14,6 & 353 \\
\hline \multicolumn{4}{|l|}{ Dried fruit } \\
\hline Cashew nuts & 1,280 & 15 & 604 \\
\hline Dried fruit & 0,848 & 12.9 & 660 \\
\hline Hazelnuts, dried & 0,930 & 13.8 & 625 \\
\hline Nuts, dried & 1,011 & 14.3 & 702 \\
\hline
\end{tabular}

(Continued)
TABLE 1 | Continued

\begin{tabular}{|c|c|c|c|}
\hline Food & $\begin{array}{l}\text { Leucine } \\
\text { (g/100 g) }\end{array}$ & $\begin{array}{c}\text { Total protein } \\
(\mathrm{g} / 100 \mathrm{~g})\end{array}$ & $\begin{array}{c}\text { Energy } \\
\text { (kcal/100 g) }\end{array}$ \\
\hline Pine nuts & 2,054 & 31,9 & 604 \\
\hline Pistachios & 1,442 & 20,6 & 570 \\
\hline Sweet almonds, dried & 1,450 & 22 & 542 \\
\hline \multicolumn{4}{|l|}{ Fruit } \\
\hline Ananas & 0,022 & 0,5 & 40 \\
\hline Apple with peel & 0,012 & 0.2 & 44 \\
\hline Apricot & 0,022 & 0,4 & 28 \\
\hline Avocado & 0,315 & 4.4 & 238 \\
\hline Banana & 0,056 & 1.2 & 76 \\
\hline Black cherry & 0,023 & 0,8 & 41 \\
\hline Bluebarry & 0,054 & 0.9 & 49 \\
\hline Cestnut & 0,207 & 3,5 & 189 \\
\hline Cherry & 0,023 & 0,8 & 38 \\
\hline Fig & 0,04 & 0,9 & 47 \\
\hline Grapes & 0,014 & 0,5 & 61 \\
\hline Kiwi & 0,068 & 1,2 & 44 \\
\hline Melon & 0,028 & 0,8 & 33 \\
\hline Orange & 0,022 & 0.7 & 37 \\
\hline Peach & 0,029 & 0,8 & 27 \\
\hline Pear & 0,016 & 0,3 & 35 \\
\hline Raspberry & 0,051 & 1 & 34 \\
\hline Strawberry & 0,046 & 0,9 & 27 \\
\hline \multicolumn{4}{|l|}{ Vegetables } \\
\hline Artichokes & 0,196 & 2,7 & 22 \\
\hline Chard & 0,093 & 1,3 & 17 \\
\hline $\begin{array}{l}\text { Coultivated mushrooms, } \\
\text { pleurotes }\end{array}$ & 0,172 & 2,2 & 37 \\
\hline Eggplant & 0,070 & 1,1 & 15 \\
\hline Forest asparagus & 0,210 & 4,6 & 35 \\
\hline Fresh lettuce & 0,115 & 1,8 & 19 \\
\hline Fresh ripe tomatoes & 0,030 & 1 & 19 \\
\hline Green beans & 0,147 & 2,1 & 18 \\
\hline Green cabage & 0,113 & 2,1 & 19 \\
\hline Pepperoni & 0,039 & 0,9 & 25 \\
\hline Porcini mushrooms & 0,207 & 3,9 & 27 \\
\hline Spinaches & 0,323 & 3,4 & 31 \\
\hline Zucchini/courgettes & 0,130 & 1,3 & 11 \\
\hline \multicolumn{4}{|l|}{ Other } \\
\hline Arachid butter & 1,465 & 22.6 & 623 \\
\hline Butter & 0,086 & 0,8 & 758 \\
\hline Chicken egg & 1,041 & 12.4 & 128 \\
\hline Chicken egg white & 0,862 & 10,7 & 43 \\
\hline Potatoes & 0,122 & 2,1 & 85 \\
\hline $\begin{array}{l}\text { Sweetened cocoa soluble } \\
\text { powder }\end{array}$ & 0,273 & 4.5 & 349 \\
\hline Unsweetened cocoa powder & 1,238 & 20.4 & 355 \\
\hline
\end{tabular}

and 23 females of $102.0 \pm 0.5$ years), Chan YC and colleagues found levels of branched chain amino acids (BCAAs) gradually lower with advancing age in both sexes (21). Similar results had 
already been reported in 1989 by Rudman D. et al., who studied fasting plasma levels of amino acids in four groups of individuals: 22 healthy young men (25-35 years), 21 healthy elderly men and self-employed (65-85 years), 23 institutionalized men with dementia, fed orally (65-92 years) and 17 institutionalized men with dementia, but artificially fed (65-88 years). The last three groups had shown significantly lower levels of BCAAs than the first group (22). And again, in another study, evaluating the amino acid concentrations in 72 healthy subjects, aged 23-92 years, divided into six groups of 12 participants each based on sex and age (20-39, 40-59 and >60 years), it was observed that the levels of total amino acids, EAAs and non-essential and branched chain amino acids decreased with increasing age; furthermore, men showed significantly higher concentrations of EAAs and BCAAs than women. Based on these data, the authors suggest that the reduction in serum amino acid concentrations may represent a consequence of the reduced energy and protein intake (evaluated in this study through a 5-day food diary) that often occurs during aging (23). Dietary intake of amino acids and its possible correlation with the skeletal muscle mass index (SMI) were evaluated in a recent Korean study in a sample of adults aged 50-64 years. The intake of leucine, isoleucine and valine (estimated through a 24 -h recall) was found to satisfy the recommended values for the Korean population and a significant positive association emerged between the intake of BCAAs with the diet (in g/day) and the SMI (24).

\section{Intervention Study With Leucine in Sarcopenic Elderly}

Most of the clinical intervention studies have been performed on subjects residing in the community and using, as a source of leucine, whey proteins, which are particularly rich in it (approximately $13 \mathrm{~g}$ of leucine/100 $\mathrm{g}$ of protein), while only in a few studies was supplementation with leucine alone used (3).

In a randomized controlled study conducted in Spain of 42 institutionalized elderly individuals (mean age $78.9 \pm 7.9$ years; 14 men and 29 women), the administration of $6 \mathrm{~g} /$ day of L-leucine for 13 weeks improved performance. functional (assessed through the measurement of pace speed) and the strength of the respiratory muscles (increase of the maximum static expiratory pressure measured at the mouth, MEP), and prevented the decline of the lean mass index (assessed through bioimpedance analysis, BIA) compared to placebo, suggesting beneficial effects of L-leucine supplementation on sarcopenia in elderly subjects. In this population, in fact, leucine would help maintain muscle mass stable over time and improve nutritional status (3). Katsanos had also observed how, while in young adults both the intake of a mixture of $6.7 \mathrm{~g}$ of essential amino acids (EAAs) containing $26 \%$ of leucine (equal to about $1.7 \mathrm{~g}$ ), both intake of an equal amount of EAAs containing $41 \%$ of this amino acid (equal to about $2.8 \mathrm{~g}$ ) were able to increase muscle protein synthesis, in elderly individuals this effect would occur only with the mixture containing the higher \% of leucine (25). A 2018 randomized controlled trial showed that both the presence of leucine ( $3 \mathrm{~g}$ twice a day), and not the total amount of protein ( $10 \mathrm{~g}$ vs. $25 \mathrm{~g}$, twice a day), is provided by supplementation for 6 days, the main responsible for the increase in myofibrillar protein synthesis in a sample of healthy women aged 65-75 years
(26). The same authors had already shown, in a previous study conducted on the same sample, how the integration with $15 \mathrm{~g}$ of a protein drink containing $4.2 \mathrm{~g}$ of leucine, taken twice a day for 6 days, caused a greater increase in synthesis myofibrillar protein compared to using $15 \mathrm{~g}$ of a similar drink, but containing only $1.3 \mathrm{~g}$ of leucine (7). Even in healthy elderly men (65-85 years of age) the intake of $5 \mathrm{~g}$ of leucine at each of the three main meals, for 3 days, improved myofibrillar protein synthesis, both in subjects with dietary protein intake equal to $0,8 \mathrm{~g} / \mathrm{kg}$ of body weight/day, as in those with a dietary intake of $1.2 \mathrm{~g}$ of protein/kg/day (27). From a 2015 meta-analysis, performed on 16 randomized controlled or cross-sectional studies with a duration ranging from 10 days to 2 years, it emerged that leucine supplementation in a total of 999 elderly individuals (2 to $7.8 \mathrm{~g}$ /day leucine, administered via amino acid mixtures, whey protein, casein, cottage cheese or protein-enriched energy drinks) was associated with a significant increase in body weight and lean mass, particularly in the subgroup of subjects diagnosed with sarcopenia; however, no effect on muscle strength was found (28). Another meta-analysis was conducted, in the same year, on 228 elderly individuals, selecting nine randomized clinical trials: of these, four investigated the acute effects of a single administration of leucine (from 2.6 to $17.6 \mathrm{~g} /$ day), while the remaining five were based on longer supplementation periods ( 10 days to 6 months; leucine between 2.8 and $16.1 \mathrm{~g} /$ day). Overall, the administration of leucine (also in this case in the form of various preparations, pure or in combination with other amino acids) was associated with a significant increase in the rate of muscle protein synthesis, but not in lean body mass and lower limbs (14). The heterogeneity of the studies analyzed makes it difficult to draw definitive conclusions, but it is plausible to admit a beneficial effect of supplementation with leucine in subjects at risk or suffering from sarcopenia (4).

\section{Recommended Amount of Leucine Intake}

In elderly individuals, the recommended amount of protein intake is $1.0-1.2 \mathrm{~g} / \mathrm{kg}$ of body weight/day, such as to maintain a positive protein status, thus obviating the altered anabolic response to proteins typical of aging; however, in the US NHANES study, it was found that up to $46 \%$ of the elderly population does not reach the average daily protein intake, recommended for adults, of $0.8 \mathrm{~g} / \mathrm{kg}$ body weight $(29,30)$. In particular, then, according to the World Health Organization (WHO), for a healthy adult the daily requirement of BCAA is equal to $39 \mathrm{mg} / \mathrm{kg}$ of body weight for leucine, $20 \mathrm{mg} / \mathrm{kg}$ for isoleucine and $26 \mathrm{mg} / \mathrm{kg}$ for valine (with no specific differences for the elderly population) (31). Furthermore, the directives of the Italian Ministry of Health had established that the intake of branched chain amino acids should not exceed $5 \mathrm{~g}$ /day (as the sum of the three) and suggest a ratio of 2:1:1 between leucine, isoleucine and valine, respectively (32).

Based on the analysis of the data reported in the literature, the PROT-AGE Study Group has proposed, for elderly individuals, an anabolic threshold of protein intake equal to $25-30 \mathrm{~g}$ of protein per meal, containing about $2.5-2.8 \mathrm{~g}$ of leucine, therefore higher than that for young adults (29). 
TABLE 2 | Nutritional composition of breakfast, lunch and dinner for each day for a week.

\begin{tabular}{|c|c|c|c|}
\hline & Breakfast & Lunch & Dinner \\
\hline \multicolumn{4}{|c|}{ Monday } \\
\hline Meal/Recipe & $\begin{array}{l}\text { Low-fat milk ( } 300 \mathrm{~g} \text { ) and rusks } \\
(30 \mathrm{~g}) \text { with peanut butter }(30 \mathrm{~g}) \\
\text { and fresh fruit (kiwi } 150 \mathrm{~g})\end{array}$ & $\begin{array}{l}\text { Pasta }(100 \mathrm{~g}) \text { with swordfish } \\
(80 \mathrm{~g}) \text { and mint } \\
\text { Salad }(50 \mathrm{~g}) \text { with cherry } \\
\text { tomatoes }(200 \mathrm{~g}) \\
\text { Greek yogurt }(125 \mathrm{~g}) \text { with dried } \\
\text { sweet almonds }(10 \mathrm{~g}) \text {, bitter } \\
\text { cocoa }(5 \mathrm{~g}) \text { and banana }(125 \mathrm{~g})\end{array}$ & $\begin{array}{l}\text { Baked zucchini omelet (two } \\
\text { eggs, zucchini } 100 \mathrm{~g} \text {, courgette } \\
\text { flowers } 2 / 3 \text {, Grana Padano } 10 \mathrm{~g} \text {, } \\
\text { olive oil } 5 \mathrm{~mL} \text {, salt, pepper, thyme } \\
\text { to taste) Toasted bread ( } 100 \mathrm{~g} \text { ) } \\
\text { with spinaches }(200 \mathrm{~g}) \text { Peach } \\
(150 \mathrm{~g}) \text { with bitter cocoa }(5 \mathrm{~g})\end{array}$ \\
\hline $\begin{array}{l}\text { Nutritional } \\
\text { composition }\end{array}$ & $\begin{array}{l}\text { E: } 507 \mathrm{kcal}(2,122,3 \mathrm{~kJ}), \mathrm{P}: 22 \mathrm{~g} \text {, } \\
\mathrm{L}: 1,9 \mathrm{~g}\end{array}$ & $\begin{array}{l}\text { E: } 841 \mathrm{kcal}(3,520,43 \mathrm{~kJ}), \mathrm{P}: \\
42.7, \mathrm{~L}: 3,15 \mathrm{~g}\end{array}$ & $\begin{array}{l}\text { E: } 681 \text { kcal }(2,850,67 \mathrm{~kJ}), \mathrm{P}: \\
37,6, \mathrm{~L}: 3,12 \mathrm{~g}\end{array}$ \\
\hline
\end{tabular}

\section{Tuesday}

Meal/Recipe

Bread (50 g) with bresaola (50 g) accompanied with whole Greek yogurt (150 g) and fruit (kiwi $100 \mathrm{~g})$

Nutritional composition

E: $369,7 \mathrm{kcal}(1,547,56 \mathrm{~kJ}), \mathrm{P}:$ $31,3 \mathrm{~g}, \mathrm{~L}: 2,5 \mathrm{~g}$

$\begin{array}{ll}\text { Meal/Recipe } & \text { Pancake (partially skimmed milk } \\ & 200 \mathrm{~g}, \text { oat flour } 50 \mathrm{~g} \text {, two egg } \\ & \text { whites: } 60 \mathrm{~g} \text { ) with hazelnut cream } \\ & \text { (toasted hazelnuts } 45 \mathrm{~g}, 1 \\ & \text { tablespoon of Stevia or other } \\ & \text { sweetener, bitter cocoa powder } \\ & 4 \mathrm{~g}, 1 \mathrm{~mL} \text { seed oil) and banana } \\ & (150 \mathrm{~g}) \text { filling } \\ \text { Nutritional } & \text { E: } 758,1 \mathrm{kcal}(3,173,41 \mathrm{~kJ}), \mathrm{P}: \\ \text { composition } & 28,5 \mathrm{~g}, \mathrm{~L}: 2,28 \mathrm{~g}\end{array}$

Meal/Recipe

French toast with avocado, pine nuts, eggs and grain flakes (one boiled egg $60 \mathrm{~g}, 1 / 2$ avocado $100 \mathrm{~g}$, bread $50 \mathrm{~g}$, parmesan $30 \mathrm{~g}$, pine nuts $15 \mathrm{~g}$ )
Nutritional
composition

Fregola with lentils (Fregola $80 \mathrm{~g}$, dry boiled lentils $100 \mathrm{~g}$, ripe tomatoes about $100 \mathrm{~g}$, Grana Padano $20 \mathrm{~g}$, extra virgin olive oil $5 \mathrm{~mL}$, vegetable broth to taste, salt to taste)

Zucchini (200 g)

Partially skimmed white yogurt $(125 \mathrm{~g})$ with honey $(10 \mathrm{~g})$ and dried nuts (20 g)

E: 773,6 kcal (3,238,29 kJ), P:
35,2 g, L: 2,744 g

\section{Wednesday}

Pasta with agretti and ricotta (100 g semolina pasta, $100 \mathrm{~g}$ cow's milk ricotta, $200 \mathrm{~g}$ agretti, $5 \mathrm{~g}$ grated parmesan, $5 \mathrm{~mL}$ extra virgin olive oil, fresh chili pepper to taste, a clove of garlic) Partially skimmed white yogurt $(125 \mathrm{~g})$ with sour cherries $(150 \mathrm{~g})$ E: 716,55 kcal (2,999,48 kJ), P: $30,35 \mathrm{~g}, \mathrm{~L}: 2,54 \mathrm{~g}$

\section{Thursday}

Risotto with shrimps, asparagus, lemon and thyme (Polished rice $100 \mathrm{~g}$, shrimps $100 \mathrm{~g}$, asparagus $100 \mathrm{~g}$, shallot to taste, juice of $1 / 2$ lemon, two sprigs of thyme, chives, salt, pepper to taste, vegetable broth to taste) Beets (200 g)

Green apple sorbet with pistachio grain (one green apple about $200 \mathrm{~g}$, sugar about $10 \mathrm{~g}$, pistachios $30 \mathrm{~g}$, water half a glass, lemon juice to taste) E: 854,5 kcal (3,576,94 kJ), P: 39,34 g, L: 2,621 g
All day

E: 2,059 kcal (8,618,97 kJ), P: 101,32 g, Li: 31,42\%, CHO: 49,5\%, S: 13,5\%, F: 27,08 g, L: $8,191 \mathrm{~g}$

Beef with grilled vegetables (Beef filet $120 \mathrm{~g}$, eggplant $100 \mathrm{~g}$, zucchini $100 \mathrm{~g}$, potatoes $350 \mathrm{~g}$, olive oil $5 \mathrm{~mL}$, vinegar to taste, salt, parsley, basil to taste) Rice crackers (2: $16 \mathrm{~g})$ Strawberries $(50 \mathrm{~g})$, peach $(50 \mathrm{~g})$, banana (50 g) E: 752,8 kcal (3,151,22 kJ), P:
34,4 g, L: 2,698 g

E: 1,976 kcal $(8,271,54 \mathrm{~kJ}), \mathrm{P}$ : 102,77 g, Li: 32,01\%, CHO: 47,07\%, S: 10,24\%, F: 28,72 g, L: $7,941 \mathrm{~g}$

Grilled tuna with orange scent (Tuna filet $100 \mathrm{~g}$, extra virgin olive oil $5 \mathrm{~mL}$, rosemary to taste, a clove of garlic, juice of one orange) Potatoes (350 g), radishes $(200 \mathrm{~g})$ and rice crackers (2: $16 \mathrm{~g})$

E: 638,42 kcal (2,672,43 kJ), P: $31,87 \mathrm{~g}, \mathrm{~L}: 2,41 \mathrm{~g}$

E: 2,053 kcal (8,593,86 kJ), P: 90,33 g, Li: 31,39\%, CHO: $50,86 \%$, S: 15,13\%, F: 29,85 g, L: 7,229 g

Chicken strips with peppers (Chicken breast $130 \mathrm{~g}$, yellow and red sweet peppers $300 \mathrm{~g}$, onion $20 \mathrm{~g}$, white wine half a glass to evaporate $70 \mathrm{~mL}$, olive oil $10 \mathrm{~mL}$, salt to taste) Bread (preferably wholemeal) (120 g) Strawberries (150 g)

E: $675 \mathrm{kcal}(2,825,55 \mathrm{~kJ}), \mathrm{P}$ : 44,8 g, L: 3,557 g
E: 2,052 kcal (8,589,67 kJ), P: 104,15 g, Li: 29,65\%, CHO: 49,94\%, S: 12,99\%, F: 27,21 g, L: $8,628 \mathrm{~g}$ 
TABLE 2 | Continued

\begin{tabular}{|c|c|c|c|c|}
\hline & Breakfast & Lunch & Dinner & All day \\
\hline \multicolumn{5}{|c|}{ Friday } \\
\hline Meal/Recipe & $\begin{array}{l}\text { Low-fat milk }(150 \mathrm{~g}) \text { and toast } \\
\text { (bread, } 50 \mathrm{~g}) \text { with smoked } \\
\text { salmon }(60 \mathrm{~g}) \text {, cream of cheese } \\
(25 \mathrm{~g}) \text { and avocado }(50 \mathrm{~g})\end{array}$ & $\begin{array}{l}\text { Spelled with peas, asparagus } \\
\text { and saffron ( } 100 \mathrm{~g} \text { spelled, } 30 \mathrm{~g} \\
\text { dried peas, } 100 \mathrm{~g} \text { asparagus, } \\
30 \mathrm{~g} \text { feta, saffron in pistils, } 5 \mathrm{~mL} \\
\text { extra virgin olive oil, salt to taste) } \\
\text { Eggplants ( } 200 \mathrm{~mL} \text { ) } \\
\text { Partially skimmed white yogurt } \\
(125 \mathrm{~g}) \text { with chopped hazelnuts } \\
(10 \mathrm{~g}) \text { and cornflakes ( } 30 \mathrm{~g})\end{array}$ & $\begin{array}{l}\text { Turkey scaloppine with kiwi } \\
\text { (Turkey breast } 110 \mathrm{~g} \text {, one kiwi } \\
80 \mathrm{~g} \text {, olive oil } 5 \mathrm{~mL} \text {, valerian } 80 \mathrm{~g} \text {, } \\
\text { flour to taste, lemon juice to } \\
\text { taste, salt to taste) Bread } \\
\text { (preferably wholemeal) }(120 \mathrm{~g} \text { ) } \\
\text { Boiled chestnuts ( } 45 \mathrm{~g} \text { ) }\end{array}$ & \\
\hline $\begin{array}{l}\text { Nutritional } \\
\text { composition }\end{array}$ & $\begin{array}{l}\text { E: 492,2 kcal (2,060,35 kJ), P: } \\
29,34 \mathrm{~g}, \mathrm{~L}: 2,46 \mathrm{~g}\end{array}$ & $\begin{array}{l}\text { E: 783,45 kcal (3,279,52 kJ), P: } \\
\text { 40,79 g, L: 3,133 g }\end{array}$ & $\begin{array}{l}\text { E: 629,8 kcal (2,636,34 kJ), P: } \\
\text { 41,4 g, L: 3,179 g }\end{array}$ & $\begin{array}{l}\text { E: 1,933 kcal (8,091,54 kJ), P: } \\
\text { 106,42 g, Li: 26,44\%, CHO: } \\
50,64 \%, \text { S: 8,54\%, F: 32,63 g, L: } \\
8,772 \mathrm{~g}\end{array}$ \\
\hline $\begin{array}{l}\text { Nutritional } \\
\text { composition }\end{array}$ & $\begin{array}{l}\text { E: 413,4 kcal (1,730,49 kJ), P: } \\
31,66 \mathrm{~g}, \mathrm{~L}: 2,6 \mathrm{~g}\end{array}$ & $\begin{array}{l}\text { E: } 797,2 \mathrm{kcal}(3,337,08 \mathrm{~kJ}), \mathrm{P}: \\
31,05 \mathrm{~g}, \mathrm{~L}: 2,562 \mathrm{~g}\end{array}$ & $\begin{array}{l}\text { E: } 796,4 \mathrm{kcal}(3,333,73 \mathrm{~kJ}), \mathrm{P}: \\
35,28 \mathrm{~g}, \mathrm{~L}: 2,611 \mathrm{~g}\end{array}$ & $\begin{array}{l}\text { E: } 2,041 \text { kcal }(8,543,63 \text { kJ), P: } \\
\text { 93,38 g, Li: 31,15\%, CHO: } \\
\text { 50,49\%, S: 11,12\%, F: 45,22 g, } \\
\text { L: } 7,773 \mathrm{~g}\end{array}$ \\
\hline \multicolumn{5}{|c|}{ Sunday } \\
\hline $\begin{array}{l}\text { Nutritional } \\
\text { composition }\end{array}$ & $\begin{array}{l}\mathrm{E}: 491 \mathrm{kcal}(2,055,33 \mathrm{~kJ}), \mathrm{P}: \\
28,5 \mathrm{~g}, \mathrm{~L}: 2,28 \mathrm{~g}\end{array}$ & $\begin{array}{l}\text { E: 804,4 kcal (3,367,22 kJ), P: } \\
\text { 32,4 g, L: 2,823 g }\end{array}$ & $\begin{array}{l}\text { E: 683,8 kcal (2,862,39 kJ), P: } \\
\text { 43,3 g, L: 3,011 g }\end{array}$ & $\begin{array}{l}\text { E: } 2,119 \mathrm{kcal}(8,870,13 \mathrm{~kJ}), \mathrm{P}: \\
103,66 \mathrm{~g}, \mathrm{Li}: 33,17 \%, \mathrm{CHO}: \\
47,36 \%, \mathrm{~S}: 12,17 \%, \mathrm{~F}: 44,44 \mathrm{~g}, \\
\text { L: } 8,113 \mathrm{~g}\end{array}$ \\
\hline
\end{tabular}

CHO, carcohydrates; E, energy; F, fiber; L, leucine; Li, lipids; P, proteins; S, sugars.

\section{Leucine in Foods and Practical Advice}

Leucine is a ubiquitous amino acid, present in all proteins, although more abundant in those of animal origin; it is therefore practically impossible to separate its intake from the total protein intake through the diet (4).

The recommended intake of $3 \mathrm{~g}$ of leucine at the three main meals together with $25-30 \mathrm{~g}$ of protein is therefore the goal to be achieved to prevent or recover the loss of lean mass in the elderly (29). Food composition databases rarely show the amounts of leucine contained in foods and therefore it becomes difficult to build a diet that follows these guidelines.

\section{CONCLUSIONS}

A table (Table 1) was therefore created for the first time in the literature in order to collect all the foods richest in leucine, thanks to the union of the two most important Italian food databases: Banca dati di composizione degli alimenti- istituto europeo di oncologia (BDA-IEO) (33) and consiglio per la ricerca in agricoltura e l'analisi dell'economia agraria (CREA) (34). The completeness of the table allows a wide choice of foods, thanks to which the amount of leucine necessary for the purpose is more easily reached. 
In order to make it easy in order to implement a diet that follows the recommendations previously provided, Table 2 shows nutritional composition of breakfast, lunch and dinner (that each provide 3 grams of leucine and 25 grams of protein) for 7 days.

\section{REFERENCES}

1. Cruz-Jentoft AJ, Bahat G, Bauer J, Boirie Y, Bruyère O, Cederholm T, et al. Sarcopenia: revised European consensus on definition and diagnosis. Age Ageing. (2019) 48:16-31. doi: 10.1093/ageing/afy169

2. von Haehling S, Anker MS, Anker SD. Prevalence and clinical impact of cachexia in chronic illness in Europe, USA, and Japan: facts and numbers update 2016. J Cachexia Sarcopenia Muscle. (2016) 7:5079. doi: $10.1002 /$ jcsm. 12167

3. Martínez-Arnau FM, Fonfría-Vivas R, Buigues C, Castillo Y, Molina $\mathrm{P}$, Hoogland AJ, et al. Effects of leucine administration in sarcopenia: a randomized and placebo-controlled clinical trial. Nutrients. (2020) 12:932. doi: 10.3390/nu12040932

4. Tessier AJ, Chevalier S. An update on protein, leucine, omega-3 fatty acids, and vitamin $\mathrm{d}$ in the prevention and treatment of sarcopenia and functional decline. Nutrients. (2018) 10:1099. doi: 10.3390/nu10081099

5. Moore DR, Robinson MJ, Fry JL, Tang JE, Glover EI, Wilkinson SB, et al. Ingested protein dose response of muscle and albumin protein synthesis after resistance exercise in young men. Am J Clin Nutr. (2009) 89:1618. doi: 10.3945/ajcn.2008.26401

6. de Bandt JP. Leucine and mammalian target of rapamycin-dependent activation of muscle protein synthesis in aging. J Nutr. (2016) 146:2616S-24S. doi: 10.3945/jn.116.234518

7. Devries MC, McGlory C, Bolster DR, Kamil A, Rahn M, Harkness L, et al. Protein leucine content is a determinant of shorter- and longer-term muscle protein synthetic responses at rest and following resistance exercise in healthy older women: a randomized, controlled trial. Am J Clin Nutr. (2018) 107:21726. doi: 10.1093/ajcn/nqx028

8. Deutz NEP, Bauer JM, Barazzoni R, Biolo G, Boirie Y, Bosy-Westphal A, et al. Protein intake and exercise for optimal muscle function with aging: recommendations from the ESPEN Expert Group. Clin Nutr. (2014) 33:92936. doi: 10.1016/j.clnu.2014.04.007

9. Egger M, Dickersin K, Smith GD. Problems and limitations in conducting systematic reviews. In: Egger M, Smith GD, Altman DG, editors. Systematic Reviews in Health Care. London, UK: BMJ Publishing Group (2001). p. 43-68. doi: 10.1002/9780470693926.ch3

10. Martínez-arnau FM, Fonfría-vivas R, Cauli O. Beneficial effects of leucine supplementation on criteria for sarcopenia: a systematic review. Nutrients. (2019) 11:2504. doi: 10.3390/nu11102504

11. Brunetta HS, de Camargo CQ, Nunes EA. Does l-leucine supplementation cause any effect on glucose homeostasis in rodent models of glucose intolerance? A systematic review. Amino Acids. (2018) 50:1663-78. doi: 10.1007/s00726-018-2658-8

12. Floyd JC, Fajans SS, Pek S, Thiffault CA, Knopf RF, Conn JW. Synergistic effect of essential amino acids and glucose upon insulin secretion in man. Diabetes. (1970) 19:109-15. doi: 10.2337/diab.19.2.109

13. Hatazawa Y, Tadaishi M, Nagaike Y, Morita A, Ogawa Y, Ezaki O, et al. PGC$1 \alpha$-mediated branched-chain amino acid metabolism in the skeletal muscle. PLoS ONE. (2014) 9:e91006. doi: 10.1371/journal.pone.0091006

14. Xu ZR, Tan ZJ, Zhang Q, Gui QF, Yang YM. The effectiveness of leucine on muscle protein synthesis, lean body mass and leg lean mass accretion in older people: a systematic review and meta-Analysis. Br J Nutr. (2015) 113:25-34. doi: 10.1017/S0007114514002475

15. Adibi SA. Metabolism of branched-chain amino acids in altered nutrition. Metabolism. (1976) 25:1287-302. doi: 10.1016/S0026-0495(76)80012-1

16. Nishioka $M$, Imaizumi $A$, Ando $T$, Tochikubo $O$. The overnight effect of dietary energy balance on postprandial Plasma Free Amino

\section{AUTHOR CONTRIBUTIONS}

MR designed and wrote the paper. $\mathrm{MNi}, \mathrm{GaP}, \mathrm{MF}, \mathrm{LO}, \mathrm{GG}$, and AT wrote and edited the paper. MNa, CG, ED, AR, GiP, and SP visualized the paper. All authors read and approved the final manuscript.

Acid (PFAA) profiles in Japanese adult men. PLoS ONE. (2013) 8:e62929. doi: 10.1371/journal.pone.0062929

17. Rousseau M, Guénard F, Garneau V, Allam-Ndoul B, Lemieux S, Pérusse L, et al. Associations between dietary protein sources, plasma BCAA and short-chain acylcarnitine levels in adults. Nutrients. (2019) 11:173. doi: 10.3390/nu11010173

18. Yamada M, Kimura $\mathrm{Y}$, Ishiyama $\mathrm{D}$, Nishio $\mathrm{N}$, Tanaka $\mathrm{T}$, Ohji $\mathrm{S}$, et al. Plasma amino acid concentrations are associated with muscle function in older Japanese women. J Nutr Heal Aging. (2018) 22:81923. doi: 10.1007/s12603-018-1014-8

19. Ottestad I, Ulven SM, Oyri LKL, Sandvei KS, Gjevestad GO, Bye A, et al. Reduced plasma concentration of branched-chain amino acids in sarcopenic older subjects: a cross-sectional study. Br J Nutr. (2018) 120:44553. doi: 10.1017/S0007114518001307

20. ter Borg S, Luiking YC, van Helvoort A, Boirie Y, Schols JMGA, de Groot CPGM. Low levels of branched chain amino acids, eicosapentaenoic acid and micronutrients are associated with low muscle mass, strength and function in community-dwelling older adults. J Nutr Heal Aging. (2019) 23:27-34. doi: 10.1007/s12603-018-1108-3

21. Chan YC, Suzuki M, Yamamoto S. A comparison of anthropometry, biochemical variables and plasma amino acids among centenarians, elderly and young subjects. J Am Coll Nutr. (1999) 18:35865. doi: 10.1080/07315724.1999.10718876

22. Rudman D, Mattson D, Feller A, Cotter R, Johnson R. Fasting plasma amino acids in elderly men. Am J Clin Nutr. (1989) 49:559-66. doi: 10.1093/ajcn/49.3.559

23. Pitkänen HT, Oja SS, Kemppainen K, Seppä JM, Mero AA. Serum amino acid concentrations in aging men and women. Amino Acids. (2003) 24:41321. doi: 10.1007/s00726-002-0338-0

24. Chae M, Park H, Park K. Estimation of dietary amino acid intake and independent correlates of skeletal muscle mass index among Korean adults. Nutrients. (2020) 12:1043. doi: 10.3390/nu12041043

25. Katsanos CS, Kobayashi H, Sheffield-Moore M, Aarsland A, Wolfe RR. A high proportion of leucine is required for optimal stimulation of the rate of muscle protein synthesis by essential amino acids in the elderly. Am J Physiol - Endocrinol Metab. (2006) 291:E381-7. doi: 10.1152/ajpendo.00488.2005

26. Devries MC, McGlory C, Bolster DR, Kamil A, Rahn M, Harkness $\mathrm{L}$, et al. Leucine, not total protein, content of a supplement is the primary determinant of muscle protein anabolic responses in healthy older women. J Nutr. (2018) 148:1088-95. doi: 10.1093/jn/nx y091

27. Murphy CH, Saddler NI, Devries MC, McGlory C, Baker SK, Phillips $\mathrm{SM}$. Leucine supplementation enhances integrative myofibrillar protein synthesis in free-living older men consuming lower-and higher-protein diets: a parallel-group crossover study1. Am J Clin Nutr. (2016) 104:1594606. doi: 10.3945/ajcn.116.136424

28. Komar B, Schwingshackl L, Hoffmann G. Effects of leucine-rich protein supplements on anthropometric parameter and muscle strength in the elderly: a systematic review and meta-analysis. J Nutr Heal Aging. (2015) 19:43746. doi: 10.1007/s12603-014-0559-4

29. Bauer J, Biolo G, Cederholm T, Cesari M, Cruz-Jentoft AJ, Morley JE, et al. Evidence-based recommendations for optimal dietary protein intake in older people: a position paper from the prot-age study group. J Am Med Dir Assoc. (2013) 14:542-59. doi: 10.1016/j.jamda.2013.0 5.021

30. Krok-Schoen JL, Archdeacon Price A, Luo M, Kelly OJ, Taylor CA. Low Dietary protein intakes and associated dietary patterns and 
functional limitations in an aging population: a NHANES analysis. $J$ Nutr Heal Aging. (2019) 23:338-47. doi: 10.1007/s12603-019$1174-1$

31. Joint WHO/FAO/UNU Expert Consultation. Protein and Amino Acid Requirements in Human Nutrition. Geneva: World Health Organization (2007). p. 1-265.

32. Ministero della sanità. Linee guida sugli alimenti adatti ad un intenso sforzo muscolare, soprattutto per gli sportivi. Gazz Uff della Repubb Ital. (1999) 135:51-2.

33. IEO. BDA. Banca Dati di Composizione degli Alimenti per studi epidemiologici in Italia. (2015). Available online at: http://www.bda-ieo.it (accessed December 17, 2020).

34. CREA. AlimentiNUTrizione - Ricerca per alimento. (2019). Available online at: https://www.alimentinutrizione.it/tabelle-nutrizionali/ricerca-peralimento (accessed August 26, 2020).
Conflict of Interest: AR and GiP were employed by Indena SpA.

The remaining authors declare that the research was conducted in the absence of any commercial or financial relationships that could be construed as a potential conflict of interest.

Copyright (๔) 2021 Rondanelli, Nichetti, Peroni, Faliva, Naso, Gasparri, Perna, Oberto, Di Paolo, Riva, Petrangolini, Guerreschi and Tartara. This is an open-access article distributed under the terms of the Creative Commons Attribution License (CC $B Y)$. The use, distribution or reproduction in other forums is permitted, provided the original author(s) and the copyright owner(s) are credited and that the original publication in this journal is cited, in accordance with accepted academic practice. No use, distribution or reproduction is permitted which does not comply with these terms. 